\title{
Larvicidal Activity against Aedes aegypti and Chemical Characterization of the Inflorescences of Tagetes patula
}

\author{
Letícia Maria Krzyzaniak, ${ }^{1}$ Tânia Mara Antonelli-Ushirobira,' \\ Gean Panizzon, ${ }^{1}$ Ana Luiza Sereia, ${ }^{1}{ }^{\prime}$ osé Roberto Pinto de Souza, ${ }^{2}$ \\ João Antonio Cyrino Zequi, ${ }^{3}$ Cláudio Roberto Novello, ${ }^{4}$ \\ Gisely Cristiny Lopes, ${ }^{1}$ Daniela Cristina de Medeiros, ${ }^{1}$ Denise Brentan Silva, \\ Eneri Vieira de Souza Leite-Mello, ${ }^{6}$ and João Carlos Palazzo de Mello ${ }^{1}$
}

\author{
${ }^{1}$ Programa de Pós-Graduação em Ciências Farmacêuticas, Department of Pharmacy, Laboratory of Pharmaceutical Biology (Palafito), \\ Universidade Estadual de Maringá, Avenida Colombo 5790, Maringá, PR, Brazil \\ ${ }^{2}$ Programa de Pós-Graduação em Agronomia, Department of Agronomy, Universidade Estadual de Londrina, \\ Rodovia Celso Garcia Cid, Km 380, s/n, Londrina, PR, Brazil \\ ${ }^{3}$ Department of Animal and Plant Biology, Universidade Estadual de Londrina, Rodovia Celso Garcia Cid, \\ Km 380, s/n, Londrina, PR, Brazil \\ ${ }^{4}$ Academic Department of Chemistry and Biology, Universidade Tecnológica Federal do Paraná, Linha Santa Bárbara, s/n, \\ Francisco Beltrão, PR, Brazil \\ ${ }^{5}$ Laboratório de Produtos Naturais e Espectrometria de Massas (LAPNEM), Universidade Federal de Mato Grosso do Sul, \\ Avenida Costa e Silva, s/n, Campo Grande, MS, Brazil \\ ${ }^{6}$ Department of Morphological Sciences, Universidade Estadual de Maringá, Avenida Colombo 5790, Maringá, PR, Brazil
}

Correspondence should be addressed to João Carlos Palazzo de Mello; mello@uem.br

Received 30 June 2017; Accepted 13 November 2017; Published 7 December 2017

Academic Editor: Ghee T. Tan

Copyright ( 2017 Letícia Maria Krzyzaniak et al. This is an open access article distributed under the Creative Commons Attribution License, which permits unrestricted use, distribution, and reproduction in any medium, provided the original work is properly cited.

The crude acetone extract (CAE) of defatted inflorescences of Tagetes patula was partitioned into five semipurified fractions: $n$ hexane (HF), dichloromethane (DF), ethyl acetate (EAF), $n$-butanol (BF), and aqueous (AQF). BF was fractionated by reversedphase polyamide column chromatography, obtaining 34 subfractions, which were subjected to HSCCC, where patuletin and patulitrin were isolated. CAE and the fractions BF, EAF, DF, and AQF were analyzed by LC-DAD-MS, and patuletin and patulitrin were determined as the major substances in EAF and BF, respectively. BF was also analyzed by HPLC and capillary electrophoresis (CE), and patulitrin was again determined to be the main substance in this fraction. CAE and the semipurified fractions (750, 500, 300,100 , and $50 \mathrm{mg} / \mathrm{L}$ ) were assayed for larvicidal activity against Aedes aegypti, with mortality rate expressed as percentage. All fractions except AQF showed insecticidal activity after $24 \mathrm{~h}$ exposure of larvae to the highest concentration. However, EAF showed the highest activity with more than $50 \%$ reduction in larval population at $50 \mathrm{mg} / \mathrm{L}$. The insecticidal activity observed with EAF might have been due to the higher concentration of patuletin present in this fraction.

\section{Introduction}

Aedes aegypti (Linnaeus, 1762) is an anthropophilic and domicile mosquito, and it is the main vector for dengue viruses in the Americas. This mosquito puts half of the world's population at risk with a 30 -fold increase in incidence in the past 50 years in more than 100 endemic countries $[1,2]$.
According to data from the World Health Organization, the number of people affected with dengue in 2015 was 3.2 million, with 500,000 people hospitalized per year [3].

Ae. aegypti also carries chikungunya, zika, and yellow fever urban viruses; so its monitoring and control are necessary. Vector control in Brazil currently occurs with the use of growth regulators of immature stages, such as 
diflubenzuron, and the control of adult mosquitoes with alpha-cypermethrin, deltamethrin, malathion, and others according to recommendations of the WHO Pesticide Evaluation Scheme [4], which are nonspecific products that select resistant insects due to their great genetic plasticity [5], with consequent environmental contamination [6].

There is currently a great deal of interest in alternative methods and selective principles for the control of mosquitoes with less environmental damage [7]. In this sense, substances extracted from plants present a great perspective for the control of Ae. aegypti.

The substances of natural origin have some advantages: they are obtained from renewable resources, and the selection of resistant forms occurs at a slower rate than with synthetic insecticides $[8,9]$. Another advantage is that they show low or no toxicity to mammals and bees [10].

Among the plants with bioactive substances, there is Tagetes patula L., popularly known as "cravo-francês," “cravo-de-defunto," or "botões-de-solteirão" [11]. T. patula belongs to the family Asteraceae, which is one of the oldest groups of higher plants [12], with approximately 300 genera and 3000 species in Brazil [13], and its flavonoids patuletin and patulitrin are considered important taxonomic markers [14].

Its inflorescences have been used in folk medicine for antiseptic, diuretic, blood purifying, and insect repellent purposes. Its leaves have been used for renal problems and muscle pain and its roots and seeds used as purgatives [15]. Some studies on the chemical composition of T. patula up to now indicate that the flowers and leaves are rich in terpenes $[16,17]$, alkaloids [18], thiophenes [19], and flavonoids [2022]. This plant has shown the following activities: antihypertensive [23], anti-inflammatory [14], hepatoprotective [24], insecticidal [25], nematicidal [26, 27], larvicidal [19], antibacterial [17], antiviral [28], and antifungal [29].

Accordingly, the aim of this work was to isolate and identify compounds from the semipurified $n$-butanol fraction of $T$. patula by reversed-phase column chromatography and high-speed countercurrent chromatography (HSCCC) and to evaluate the chemical profile of the crude extract and semipurified fractions using high performance liquid chromatography (HPLC), capillary electrophoresis (CE), and liquid chromatography-mass spectrometry (LC-DAD-MS). In addition, the larvicidal activity of the crude extract and semipurified fractions was evaluated against Ae. aegypti.

\section{Materials and Methods}

2.1. Plant Material. The inflorescences of $T$. patula were collected in November 2011 in the Garden of Medicinal Plants of the Universidade Estadual de Londrina, Londrina, Brazil, where they were organically grown. The plant material was collected under a permit from IBAMA-SISBIO, number 11995-6, May 13, 2016, authentication code 48926652, under the responsibility of J. C. P. Mello. An exsiccate is deposited at the Herbarium of the Universidade Estadual de Maringá (HUEM) under number 21907, and the identification was provided by Professor Dr. Jimi Nakajima at the Institute
TABLE 1: Eluent systems used for HSCCC to obtain subfractions.

\begin{tabular}{lc}
\hline Subfraction & Eluent systems $(\mathrm{v} / \mathrm{v})$ \\
\hline & hexane : ethyl acetate $:$ methanol $:$ water $(2: 2: 2.5: 2)$ \\
& Gradient elution with $n$-butanol: \\
& $0-400 \mathrm{~mL}-0 \mathrm{~mL} n$-butanol \\
& $400-800 \mathrm{~mL}-20 \mathrm{~mL} n$-butanol \\
FB\#16 & $800-1200 \mathrm{~mL}-30 \mathrm{~mL} n$-butanol \\
& $1200-1400 \mathrm{~mL}-40 \mathrm{~mL} n$-butanol \\
& hexane : ethyl acetate $:$ methanol : water $(1: 5: 1: 5)$ \\
\hline FB\#23 & hexane : ethyl acetate : methanol : water $(2: 2: 2.5: 2)$ \\
\hline FB\#26
\end{tabular}

of Biology of the Universidade Federal de Uberlândia, Uberlândia, Brazil. The flowers were dried in a convection oven at $38^{\circ} \mathrm{C}$ for $48 \mathrm{~h}$. The dried plant material was macerated using a hammer mill (Tigre ASN-5).

\subsection{Preparation of Crude Extract and Semipurified Fractions.} The milled inflorescences $(1.9 \mathrm{~kg})$ were defatted with $n$ hexane by dynamic maceration for three days, with subsequent drying of the inflorescences at room temperature. Afterwards, acetone was used as extraction solvent at a proportion of $4 \%(\mathrm{w} / \mathrm{v})$ in an Ultra-Turrax ${ }^{\circledR}$ (UTC115KT, Ika Works) for $5 \mathrm{~min}$ and then subjected to maceration for $15 \mathrm{~h}$. Next, turbo-extraction was performed for $20 \mathrm{~min}$, with intervals of $5 \mathrm{~min}\left(t<40^{\circ} \mathrm{C}\right)$. The extract was filtered, concentrated under reduced pressure, frozen, and lyophilized (Alpha 1-4, Christ $^{\circledR}$ ) to give the crude acetone extract (CAE, 5.86\%). CAE was fractionated according to Filho and Yunes [30]. Briefly, $105 \mathrm{~g} \mathrm{CAE}$ was resuspended in $1 \mathrm{~L}$ of methanol: water $(2: 8, \mathrm{v} / \mathrm{v})$ and partitioned with different solvent volume ratios. The yields were $n$-hexane (HF) $19.27 \%$, dichloromethane (DF) $10.17 \%$, ethyl acetate (EAF) $13.38 \%, n$ butanol (BF) 36.59\%, and aqueous (AQF) 15.02\%.

\subsection{Reversed-Phase Column Chromatography of n-Butanol} Fraction. BF (20.0 g) was separated by column chromatography (CC) with a polyamide column (CC6 Korngrobe, 0.05-0.16 mm; Macherey Nagel) according to Degani et al. [31], and the mobile phase was $100 \%$ methanol or water or a combination thereof, providing 34 subfractions (BF\#1-34). The subfractions BF\#6 (25 mg) and BF\#11 (5 mg) precipitated during the organic solvent removal process and were analyzed by nuclear magnetic resonance (NMR), MS, and HPLC.

2.4. High-Speed Countercurrent Chromatography (HSCCC). The subfractions $\mathrm{BF} \# 16, \mathrm{BF} \# 23$, and $\mathrm{BF} \# 26$ were rechromatographed by HSCCC using a PC Ito $^{\circledR}$ chromatograph (model 001) equipped with a polytetrafluoroethylene (PTFE) column ( $2.5 \mathrm{~mm}$ i.d., total volume capacity of $320 \mathrm{~mL}$ ), $10-\mu \mathrm{L}$ sample loop, $800 \mathrm{rpm}$, and double piston solvent pump (Waters model 510), using a flow-rate of $1.0 \mathrm{~mL} / \mathrm{min}$. The organic phase (hexane: ethyl acetate: methanol: water; Table 1) was used as the mobile phase, and water was the stationary phase. Only in HSCCC of BF\#16 was a gradient system with $n$-butanol also used. $\mathrm{BF} \# 16, \mathrm{BF} \# 23$, and $\mathrm{BF} \# 26$ 
yielded 8,15 , and 18 subfractions, respectively. The subfractions BF\#16.5 (7 mg), BF\#23.4 (13 mg), BF\#26.6 (4.5 mg), and $\mathrm{BF} \# 26.15$ (5 mg) were selected and analyzed by NMR and MS.

2.5. NMR Analysis. The subfractions BF\#6, BF\#11, BF\#16.5, $\mathrm{BF} \# 23.4, \mathrm{BF} \# 26.6$, and $\mathrm{BF} 26.15$ were analyzed by NMR spectroscopic methods $1 \mathrm{D}\left({ }^{1} \mathrm{H}\right.$ and $\left.{ }^{13} \mathrm{C}\right)$ and $2 \mathrm{D}\left({ }^{1} \mathrm{H} /{ }^{1} \mathrm{H}-\right.$ COSY and HMBC), with a Varian Mercury Plus $300(75 \mathrm{MHz}$ for ${ }^{13} \mathrm{C}$ and $300 \mathrm{MHz}$ for $\left.{ }^{1} \mathrm{H}\right)$, using deuterated solvents and TMS as internal reference. The spectra of the subfractions were related to the compounds Tp1 (BF\#23.4, \#26.6, and \#26.15) and Tp2 (BF\#6, \#11, and \#16.5), which were analyzed and compared to literature data.

Patuletin (Tp1) ${ }^{1} \mathrm{H}-\mathrm{NMR}\left(\mathrm{CD}_{3} \mathrm{OD}, 300 \mathrm{MHz}\right) .6 .48(\mathrm{H}-8)$, 7.72 (d, J 2.0 Hz, H-2'), 6.88 (d, J $8.08 \mathrm{~Hz}, \mathrm{H}-5^{\prime}$ ), 7.63 (dd, J $\left.8.6 \mathrm{~Hz} ; 2.0 \mathrm{~Hz}, \mathrm{H}-6^{\prime}\right), 3.88\left(\mathrm{OCH}_{3}-6\right) .{ }^{13} \mathrm{C}-\mathrm{NMR}\left(\mathrm{CD}_{3} \mathrm{OD}\right.$, $75 \mathrm{MHz}$ ): 146.9 (C-2), 135.6 (C-3), 176.2 (C-4), 151.6 (C-5), 130.8 (C-6), 157.1 (C-7), 93.4 (C-8), 152.3 (C-9), 103.5 (C-10), $120.3\left(\mathrm{C}-1^{\prime}\right), 114.6\left(\mathrm{C}-2^{\prime}\right), 144.8\left(\mathrm{C}-3^{\prime}\right), 147.4\left(\mathrm{C}-4^{\prime}\right), 114.8(\mathrm{C}-$ $\left.5^{\prime}\right), 122.8\left(\mathrm{C}-6^{\prime}\right), 59.60(\mathrm{CH} 3-6)$.

Patulitrin (Tp2) ${ }^{1} \mathrm{H}-\mathrm{NMR}\left(\mathrm{CD}_{3} \mathrm{OD}, 300 \mathrm{MHz}\right) .6 .93$ (s) (H8), 7.72 (d, J 2.2 Hz, H-2' ), 6.89 (d, J $8.5 \mathrm{~Hz}, \mathrm{H}-5^{\prime}$ ), 7.54 (dd, J $\left.8.5 \mathrm{~Hz} ; 2.1 \mathrm{~Hz}, \mathrm{H}-6^{\prime}\right), 5.13\left(\mathrm{~d} ; J 7.2, \mathrm{H}-1^{\prime \prime}\right), 3.32\left(\mathrm{~d} ; J 2,2, \mathrm{H}-2^{\prime \prime}\right)$ $3.45(\mathrm{~m})\left(\mathrm{H}-3^{\prime \prime}\right), 3.17(\mathrm{~m})\left(\mathrm{H}-4^{\prime \prime}\right), 3.48(\mathrm{~m})\left(\mathrm{H}-5^{\prime \prime}\right), 3.72(\mathrm{~m})$ $\left(\mathrm{H}-6{ }^{\prime \prime}\right), 3.78$ (s) $\mathrm{CH}_{3} \mathrm{O}-6 .{ }^{13} \mathrm{C}-\mathrm{NMR}\left(\mathrm{CD}_{3} \mathrm{OD}, 75 \mathrm{MHz}\right): 147.9$ (C-2), 135.8 (C-3), 176.2 (C-4), 151.1 (C-5), 131.8 (C-6), 156.4 (C-7), 93.8 (C-8), 151.4 (C-9), 105.0 (C-10), 120.0 (C-1'), 115.5 $\left(\mathrm{C}-2^{\prime}\right), 145.0\left(\mathrm{C}^{\prime}\right), 147.7\left(\mathrm{C}-4^{\prime}\right), 115.4\left(\mathrm{C}-5^{\prime}\right), 121.8\left(\mathrm{C}-6^{\prime}\right), 100.1$ $\left(\mathrm{C}-1^{\prime \prime}\right), 73.2\left(\mathrm{C}-2^{\prime \prime}\right), 77.2\left(\mathrm{C}-3^{\prime \prime}\right), 69.5\left(\mathrm{C}-4^{\prime \prime}\right), 76.7\left(\mathrm{C}-5^{\prime \prime}\right), 60.6$ $\left(\mathrm{C}-6^{\prime \prime}\right), 60.3\left(\mathrm{CH}_{3} \mathrm{O}-6\right)$.

2.6. HPLC-ESI-MS/MS Analysis. Fractions and subfractions were analyzed with a Waters HPLC system coupled with a triple quadrupole mass spectrometer (Micromass, Quattro micro $^{\mathrm{TM}} \mathrm{API}$ ) equipped with a Z-electrospray ionization (ESI) source (Waters) and processed by MassLynx ${ }^{\mathrm{TM}}$ software (version 4.0, Waters). Chromatographic conditions were as follows: column was a Symmetry C-18 $(3.5 \mu \mathrm{m}, 75 \times 4.6 \mathrm{~mm}$, Waters); mobile phase was water with $0.1 \%$ formic acid $(\mathrm{v} / \mathrm{v})$ (solvent A) and acetonitrile with $0.1 \%$ formic acid (v/v) (solvent $\mathrm{B}$ ). The gradient system employed was as follows: 0-2 $\min 5 \%$ B; 10 min 50\% B; 2 min 50\%; and $13-15 \min 5 \%$ B. The flow rate was $0.5 \mathrm{~mL} / \mathrm{min}$ and the injection volume $10 \mu \mathrm{L}$. A sample containing $1000 \mathrm{ng} / \mathrm{mL}$ of the isolated substances was injected, and identification was performed analyzing the information of the product ion spectra in comparison to a previously published dataset.

2.7. Identification of the Constituents by LC-DAD-MS. The analyses of CAE and the fractions DF, EAF, BF, and AQF were performed on UFLC Shimadzu Prominence chromatograph coupled to a diode array detector (DAD) and MicrOTOFQ III mass spectrometer (Bruker Daltonics). A Kinetex C18 chromatographic column $(2.6 \mu \mathrm{m}, 150 \times 2.1 \mathrm{~mm}$, Phenomenex) was used. Acetonitrile (solvent B) and deionized water (solvent $\mathrm{A}$ ), both with $0.1 \%$ formic acid $(\mathrm{v} / \mathrm{v})$, were used as mobile phase. The gradient elution profile was the following: initial 3\% B, 2-25 min 25\% B, 25-40 min $80 \% \mathrm{~B}$, and $40-43 \min 80 \% \mathrm{~B}$. The negative and positive ion modes were carried out, and nitrogen was applied as a nebulizer gas (4 bar) and dry gas ( $9 \mathrm{~L} / \mathrm{min})$.

2.8. Capillary Electrophoresis (CE). CE for BF analysis was carried out using a Beckman $\mathrm{P} / \mathrm{ACE}^{\mathrm{TM}} \mathrm{MDQ}$ electrophoresis system equipped with a filter-based UV/Vis detector and 32 Karat $^{\mathrm{TM}}$ version 7.0 software. The column used was a fused silica capillary column (Beckman-Coulter) with dimensions of $60.2 \mathrm{~cm}$ total length, $50.0 \mathrm{~cm}$ effective length, $363 \mu \mathrm{m}$ o.d., and $75 \mu \mathrm{m}$ i.d. The sample was injected hydrodynamically at $0.5 \mathrm{psi}$ for $3 \mathrm{~s}, 30 \mathrm{kV}$, and the electropherogram was recorded at $214 \mathrm{~nm}$. The cartridge coolant of the $\mathrm{CE}$ was set with a thermostat at $25^{\circ} \mathrm{C}$. The background electrolyte consisted of $80 \mathrm{mmol} / \mathrm{L}$ borate buffer ( $\mathrm{pH} 8.80$ ) containing $10 \mathrm{mmol} / \mathrm{L}$ methyl- $\beta$-cyclodextrin (Me- $\beta$-CD). The sample solution $(500 \mu \mathrm{g} / \mathrm{mL})$ was prepared by dissolving $5 \mathrm{mg} \mathrm{BF}$ in $10 \mathrm{~mL}$ of $20 \%$ methanol and was eluted through the solid-phase extraction (SPE) cartridge (Strata C18-E, Phenomenex), preconditioned with methanol and water. Tp1 and Tp2 were used as standards for peak identification. All solutions were filtered with $0.45 \mu \mathrm{m}$ Millipore filters.

2.9. Evaluation of Larvicidal Activity. CAE, AQF, EAF, HF, $\mathrm{BF}, \mathrm{DF}$, and the fatty waste obtained in the preparation of the crude extract were tested for larvicidal activity.

Immature forms of Ae. aegypti were obtained from the insectary of the Malaria and Dengue Laboratory, Instituto Nacional de Pesquisas da Amazônia (INPA), Manaus, Brazil. The insectary began with the collection of eggs in the field by using traps (egg traps). All the procedures for the maintenance of mosquitoes and the use of animals for blood meal were authorized by the Animal Experiment Ethics Committee (CEUA/INPA 04/2013). The bioassay methods were according to Lacey [32], and WHO [33, 34], with modifications.

Fourth instar larvae were used for all experiments. Three replicates with 15 immature forms and $50 \mathrm{~mL}$ of distilled water per container were assayed. The crude extract and semipurified fractions were diluted in dimethyl sulfoxide (DMSO) at an initial concentration of $30,000 \mathrm{mg} / \mathrm{L}$ in a total volume of $10 \mathrm{~mL}$. The samples were solubilized using an ultrasonic bath for $15 \mathrm{~min}$. To determine mortality rates in percent, lethal concentrations $\left(\mathrm{LC}_{50}\right.$ and $\left.\mathrm{LC}_{90}\right)$, and their limits, five concentrations were used: 750, 500, 300, 100, and $50 \mathrm{mg} / \mathrm{L}$. DMSO solution at $300 \mathrm{mg} / \mathrm{L}$ and distilled water were used as controls. The assay was performed using a photoperiod of $12 / 12 \mathrm{~h}$, at $26 \pm 2^{\circ} \mathrm{C}$. Mortality readings were performed at $24,48,72,96$, and $120 \mathrm{~h}$.

Statistical package Spss Inc. 2005 was used for the calculation of the survival curve of the fractions and the lethal time of Ae. aegypti for EAF.

\section{Results and Discussion}

3.1. Structural Analysis. The structural analysis of subfractions BF\#6, BF\#11, BF\#16.5, BF\#23.4, BF\#26.6, and BF\#26.15 


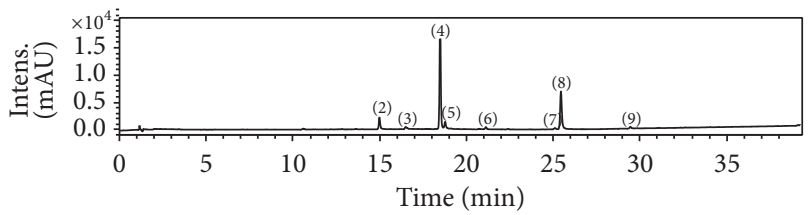

(a)

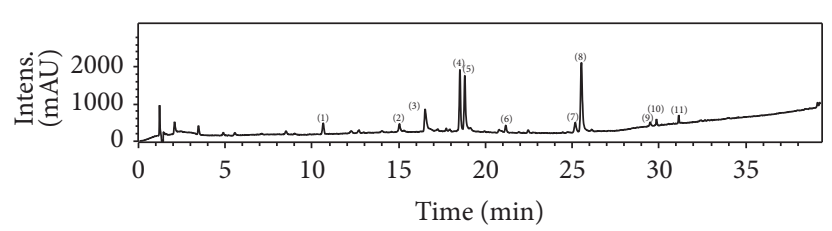

(c)

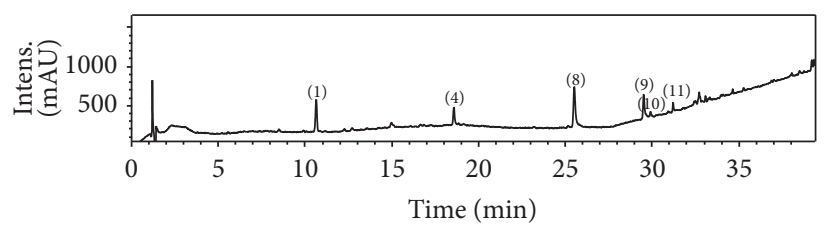

(b)

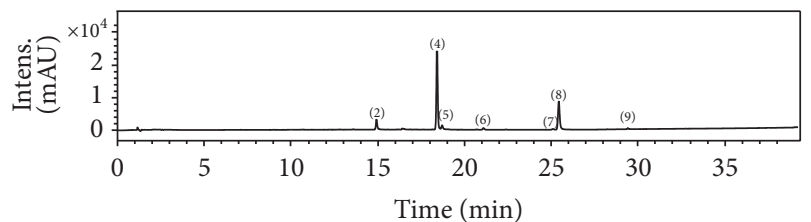

(d)

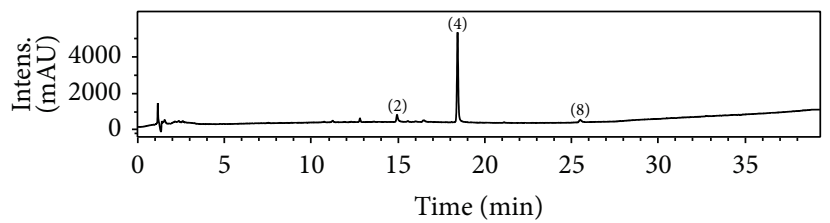

(e)

Figure 1: Chromatogram at 240 to $350 \mathrm{~nm}$ of the crude acetone extract of Tagetes patula (a) and its fractions obtained with dichloromethane (b), ethyl acetate (c), $n$-butanol (d), and water (e). The identification of the constituents is given in Table 2.

was performed by NMR, HPLC-IES-MS/MS and LC-DADMS and resulted in the identification of the compounds Tp1 and Tp2.

Tp1 (BF\#23.4, BF\#26.6, and BF\#26.15) was obtained as a yellow powder. The mass spectrum obtained by ESI showed an intense ion peak at $m / z 333$, corresponding to the protonated ion and fragment ions of $\mathrm{m} / z 288$ and 318. The UV spectrum of Tp1 revealed two absorption maxima in the region of $257 \mathrm{~nm}$ (band I) and $372 \mathrm{~nm}$ (band II), compatible with the UV spectrum of flavonols.

Tp2 (BF\#6, BF\#11, and BF\#16.5) was also obtained as a yellow powder. Its mass spectrum showed an intense ion of $m / z 495$ and fragment ions at $m / z 318$ and 333. The UV spectrum of $\mathbf{T p} 2$ revealed maxima at $258 \mathrm{~nm}$ (band I) and 371 (band II), which was also compatible with flavonols.

On the basis of ${ }^{1} \mathrm{H}$ and ${ }^{13} \mathrm{C}-\mathrm{NMR}$ data obtained and comparison with literature values [35-37], Tp1 and Tp2 were identified as the flavonols patuletin and patuletin-7-O- $\beta$ glycoside (patulitrin), respectively, which was confirmed by HMBC, HSQC, and COSY data.

$\mathrm{CAE}$ and $\mathrm{AQF}, \mathrm{EAF}, \mathrm{DF}$, and BF from T. patula were analyzed by LC-DAD-MS, and the compounds were identified on the basis of UV and accurate mass and fragmentation data, which were compared with the literature data. From the samples, eleven compounds were detected and identified (Figure 1, Table 2). The higher peak intensity was compound 4 (patulitrin) for $\mathrm{BF}$ and $\mathrm{AQF}$, compounds 4, 5 (patulitrin isomer), and 8 (patuletin) for EAF, compound 8 for DF, and compounds 4 and 8 for CAE (Figure 1).

3.2. CE Fingerprint of BF of T. patula. In this work, BF of T. patula was evaluated by CE. The major peaks were identified by addition of the isolated substances of this work. Peak 1 was identified as Tp2 2 and peak 2 as Tpl (Figure 2). This fingerprint shows that the major substance was $\mathrm{Tp} 2$, and the same profile was observed by LC-DAD-MS analysis (Figure 1).

Some studies with $T$. patula have been performed using thin layer chromatography (TLC), HPLC, and HPLC-MS $[19,38]$. However, CE was employed here for the first time to identify the compounds obtained from T. patula.

Comparing the HPLC and CE methods developed for evaluation of $\mathrm{BF}$ of $T$. patula, $\mathrm{CE}$ was more efficient, being almost four times faster. In addition, in the CE method, organic solvents are not used to separate the analytes, and the volume of electrolytic solution used for analyses is small, making the technique less costly and polluting [39-41].

3.3. Larvicidal Activity. All the fractions of T. patula evaluated showed insecticidal activity against Ae. aegypti after $24 \mathrm{~h}$ exposure of the larvae to a concentration of $750 \mathrm{mg} / \mathrm{L}$, with exception of AQF.

After $120 \mathrm{~h}$ (5 days) of exposure, the following mortality rates were observed at a concentration of $300 \mathrm{mg} / \mathrm{L}$ for the different samples evaluated: CAE (31.0\%), AQF (17.8\%), EAF (53.0\%), HF (13.0\%), BF (15.6\%), DF (8.9\%), and fatty waste (31.0\%). No deaths occurred during a four-day observation period for the DMSO control, but at the end of the fifth day, mortality was $6.7 \%$. The distilled water control did not cause any mortality during the whole experiment period (Table 3).

EAF and fatty waste showed the best time-dependent results (Figure 3). The lethal time for 50 percent mortality $\left(\mathrm{LT}_{50}\right)$ of Ae. aegypti with EAF was $96.7 \mathrm{~h}$ (range: $78.4-134.8 \mathrm{~h})$.

Komalasmisra et al. [42] demonstrated that plants with a $\mathrm{LC}_{50}$ lower than $750 \mathrm{mg} / \mathrm{L}$ for larvicidal activity are effective against Ae. aegypti. Thus, CAE and all fractions evaluated, 
TABLE 2: Identification of the constituents from Tagetes patula by LC-DAD-MS.

\begin{tabular}{|c|c|c|c|c|c|c|c|c|}
\hline \multirow{2}{*}{ Peak } & \multirow{2}{*}{$\mathrm{RT}(\min )$} & \multirow{2}{*}{ Compound } & \multirow{2}{*}{$\mathrm{UV}(\mathrm{nm})$} & \multirow{2}{*}{ MF } & \multicolumn{2}{|c|}{ Negative mode $(\mathrm{m} / z)$} & \multicolumn{2}{|c|}{ Positive mode $(\mathrm{m} / \mathrm{z})$} \\
\hline & & & & & $\operatorname{MS}\left({ }^{*}\right)$ & MS/MS & $\operatorname{MS}\left({ }^{*}\right)$ & MS/MS \\
\hline (1) & 10.6 & NI & 274 & & & & & \\
\hline (2) & 15.0 & $\begin{array}{l}\text { Quercetagetin } \\
\text { O-hexoside }\end{array}$ & 270,355 & $\mathrm{C}_{21} \mathrm{H}_{20} \mathrm{O}_{13}$ & 479.0822 & $317,195,167$ & 481.0969 & $\begin{array}{c}319,273,199 \\
181,169\end{array}$ \\
\hline (3) & 15.5 & Ellagic acid ${ }^{\text {st }}$ & 290,360 & $\mathrm{C}_{14} \mathrm{H}_{6} \mathrm{O}_{8}$ & 300.9990 & $284,245,229$ & 303.0117 & $\begin{array}{c}285,275,257, \\
247\end{array}$ \\
\hline (4) & 18.5 & Patulitrin $^{\text {st }}$ & 257,369 & $\mathrm{C}_{22} \mathrm{H}_{22} \mathrm{O}_{13}$ & 493.0978 & $\begin{array}{l}331,316,287 \\
271,181,166\end{array}$ & 495.1142 & $\begin{array}{c}333,318,301, \\
273\end{array}$ \\
\hline (5) & 18.8 & Patulitrin isomer & 260,351 & $\mathrm{C}_{22} \mathrm{H}_{22} \mathrm{O}_{13}$ & 493.0975 & $330,315,287$ & 495.1106 & 333,318 \\
\hline (6) & 21.2 & $\begin{array}{l}\text { Isorhamnetin } \\
\text { O-hexoside }\end{array}$ & 270,360 & $\mathrm{C}_{22} \mathrm{H}_{22} \mathrm{O}_{12}$ & 477.1041 & $\begin{array}{c}314,299,271 \\
181,166\end{array}$ & 479.1203 & 317,302 \\
\hline (7) & 25.2 & Kaempferol & 267,345 & $\mathrm{C}_{15} \mathrm{H}_{10} \mathrm{O}_{6}$ & 285.0391 & 175 & 287.0547 & $241,161,153$ \\
\hline (8) & 25.5 & Patuletin $^{\text {st }}$ & 257,369 & $\mathrm{C}_{16} \mathrm{H}_{12} \mathrm{O}_{8}$ & 331.0462 & $\begin{array}{c}316,287,271 \\
181,166\end{array}$ & 333.0613 & $318,290,273$ \\
\hline (9) & 29.5 & $\begin{array}{c}\text { O-Methyl } \\
\text { kaempferol }\end{array}$ & 270,355 & $\mathrm{C}_{16} \mathrm{H}_{12} \mathrm{O}_{7}$ & 315.0502 & $\begin{array}{c}300,271,255 \\
243,166\end{array}$ & 317.0655 & $\begin{array}{c}302,274,257 \\
245,169\end{array}$ \\
\hline (10) & 29.9 & $\begin{array}{l}\text { Tricoumaroyl } \\
\text { spermidine }\end{array}$ & 299,310 & $\mathrm{C}_{34} \mathrm{H}_{37} \mathrm{~N}_{3} \mathrm{O}_{6}$ & 582.2591 & - & 584.2775 & $\begin{array}{c}438,420,292 \\
275,218,204 \\
146\end{array}$ \\
\hline (11) & 31.2 & $\begin{array}{l}\text { Coumaroyl } \\
\text { spermidine } \\
\text { derivative }\end{array}$ & 296,306 & $\mathrm{C}_{41} \mathrm{H}_{50} \mathrm{~N}_{6} \mathrm{O}_{10}$ & 785.3517 & - & 787.3690 & $\begin{array}{l}641,623,495, \\
477,275,204\end{array}$ \\
\hline
\end{tabular}

RT: retention time; MF: molecular formula; ${ }^{*}$ error lower than $8 \mathrm{ppm} ;{ }^{\text {st }}$ confirmed by authentic standard.

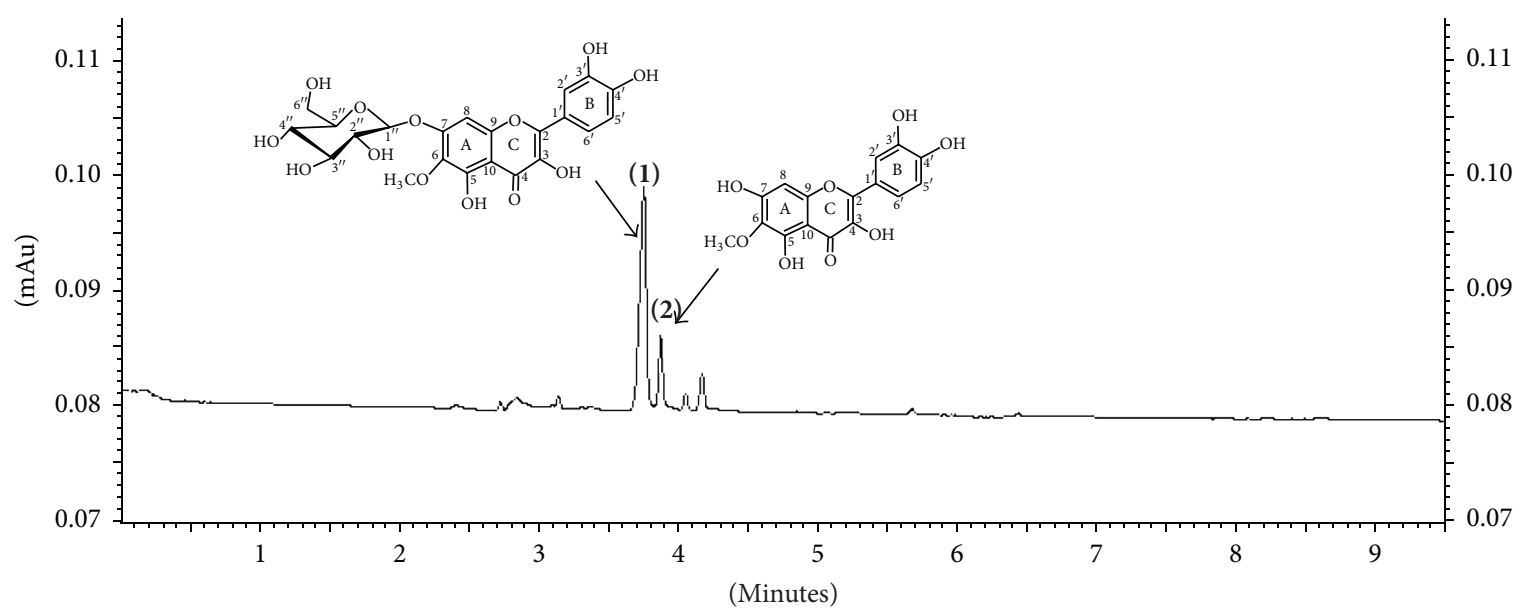

FIGURE 2: CE-UV electropherogram of the $n$-butanol fraction of Tagetes patula. Experimental conditions: $80 \mathrm{mmol} / \mathrm{L}$ borate buffer at $\mathrm{pH} 8.80$ with $10 \mathrm{mmol} / \mathrm{L} \mathrm{Me}-\beta$-CD; uncoated fused-silica capillary column, $60.2 \mathrm{~cm}(50 \mathrm{~cm}$ effective length $) \times 75 \mu \mathrm{m}$ i.d.; $30 \mathrm{kV} ; 25^{\circ} \mathrm{C}$; hydrodynamic injection $0.5 \mathrm{psi} \times 5 \mathrm{~s}$; detection at $214 \mathrm{~nm}$; BF: $500 \mu \mathrm{g} / \mathrm{mL}$. Peaks: (1) Tp2 (patulitrin); (2) Tp1 (patuletin).

with the exception of AQF, showed notable larvicidal activity in the present study. Among the fractions analyzed, EAF was the most promising, where a concentration as low as $50 \mathrm{mg} / \mathrm{L}$ reduced the larval population by more than half, and where $750 \mathrm{mg} / \mathrm{L}$ caused the death of all larvae within $96 \mathrm{~h}$.

Faizi et al. [27] carried out a nematicidal study with flowers of T. patula, which were first subjected to a defatting process with petroleum ether and then extracted with methanol, finally resulting in aqueous, dichloromethane, ethyl acetate, and butanol fractions. In that study, EAF had a higher concentration of patuletin, while the BF showed a lower amount of this substance. The authors reported that patuletin is generally more potent than patulitrin in other biological assays, such as antimicrobial and antioxidant.

Comparing our results of larvicidal activity against $A e$. aegypti with those for nematicidal activity against Heterodera zeae reported by Faizi et al. [27], it is observed that, in both studies, the fraction with better activity was that with a higher concentration of patuletin and lower level of patulitrin. Thus, it is suggested that the larvicidal activity observed in EAF may 
TABLE 3: Percentage of mortality of Aedes aegypti larvae exposed to different fractions of Tagetes patula under laboratory conditions at $300 \mathrm{mg} / \mathrm{L}$, for $120 \mathrm{~h}$.

\begin{tabular}{|c|c|c|c|c|c|}
\hline Sample & $24 \mathrm{~h}$ & $48 \mathrm{~h}$ & $72 \mathrm{~h}$ & $96 \mathrm{~h}$ & $120 \mathrm{~h}$ \\
\hline Crude acetone extract & 0 & 4.4 & 22.0 & 26.7 & $31.0^{\mathrm{B}}$ \\
\hline Fatty waste & 0 & 4.4 & 16.0 & 24.4 & $31.0^{\mathrm{B}}$ \\
\hline Aqueous fraction & 0 & 0 & 0 & 0 & $17.8^{\mathrm{B} *}$ \\
\hline Ethyl acetate fraction & 22.0 & 31.0 & 38.0 & 49.0 & $53.0^{\mathrm{A}}$ \\
\hline$n$-Hexane fraction & 2.0 & 4.4 & 4.4 & 4.4 & $13.0^{\mathrm{B}}$ \\
\hline$n$-Butanol fraction & 0 & 11.0 & 13.0 & 13.3 & $15.6^{\mathrm{B}}$ \\
\hline Dichloromethane fraction & 4.4 & 4.4 & 8.9 & 8.9 & $8.9^{\mathrm{B}}$ \\
\hline DMSO & 0 & 0 & 0 & 0 & $6.7^{\mathrm{B}}$ \\
\hline Distilled water & 0 & 0 & 0 & 0 & $0^{\mathrm{B}}$ \\
\hline
\end{tabular}

${ }^{*}$ Numbers followed by same letters in a column do not differ according to Tukey test $(p=0.01)$.

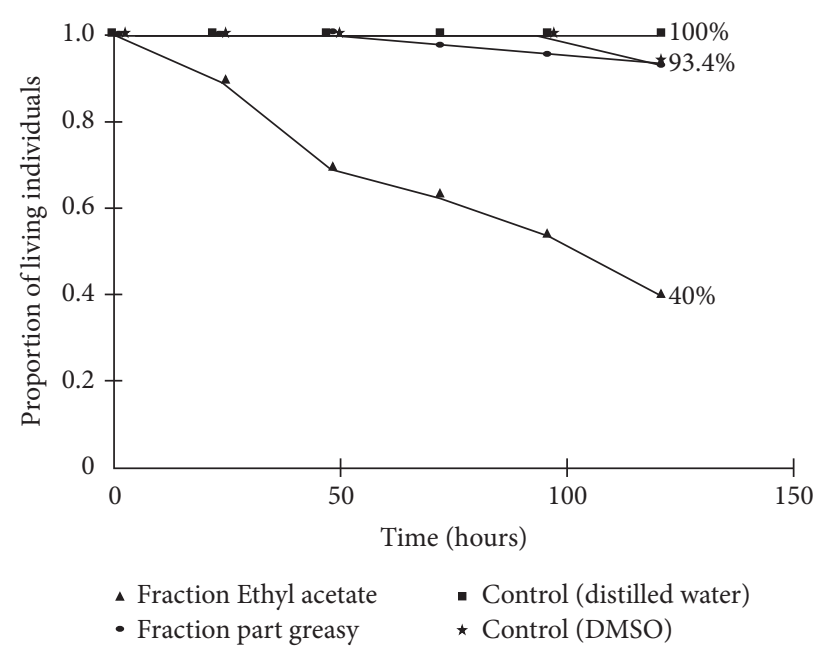

FIGURE 3: Survival rates (log-rank test) of the immature stages of Ae. aegypti exposed to controls (distilled water and DMSO), ethyl acetate fraction, and fatty waste of Tagetes patula at $50 \mathrm{mg} / \mathrm{L}$, for 120 h ( $p<0.0001$; variance: 13.96; chi-square: 191.38).

be due to the higher concentration of patuletin seen in this fraction.

\section{Conclusion}

Among the semipurified fractions obtained from CAE of the inflorescences of $T$. patula, BF showed a higher yield of the flavonoids patuletin and patuletin-7-O- $\beta$-glycoside (patulitrin).

LC-DAD-MS analysis of CAE and the fractions DF, EAF, $\mathrm{BF}$, and $\mathrm{AQF}$ confirmed that the main substance in EAF was patuletin and patulitrin in $\mathrm{BF}$.

EAF showed the highest larvicidal activity against $A e$. aegypti with more than $50 \%$ decrease in larval population at a concentration of $50 \mathrm{mg} / \mathrm{L}$. This high insecticidal activity observed in EAF may be due to the higher concentration of patuletin in this fraction.

\section{Conflicts of Interest}

The authors have declared no conflicts of interest.

\section{Acknowledgments}

The authors thank the Brazilian agencies Coordenação de Aperfeiçoamento de Pessoal de Nível Superior (CAPES), Conselho Nacional de Desenvolvimento Científico e Tecnológico (CNPq), Instituto Nacional de Ciência e Tecnologia para Inovação Farmacêutica (INCT if), and Fundação Araucária and Programa de Pós-Graduação em Ciências Farmacêuticas for their financial support. Dr. A. Leyva (USA) helped with English editing of the manuscript.

\section{Supplementary Materials}

Figure S1. High performance liquid chromatography fingerprint of $\mathrm{CAE}(\mathrm{A})$ and $\mathrm{BF}(\mathrm{B})$ from the inflorescences of Tagetes patula. Peaks: (1) Tp2 (patulitrin) and (2) Tp1 (patuletin). (Supplementary Materials)

\section{References}

[1] B. Galli and F. Chiaravalloti Neto, "Modelo de risco tempoespacial para identificação de áreas de risco para ocorrência de dengue," Revista de Saúde Pública, vol. 42, no. 4, pp. 656-663, 2008.

[2] World Health Organization, Dengue: Guidelines for Diagnosis, Treatment, Preventions and Control, 2009.

[3] World Health Organization, "Dengue and severe dengue," 2017.

[4] Whopes, "World Health Organization Pesticides Evaluation Scheme," 2016.

[5] A. E. Eiras, "Culicidae," in Parasitologia humana, D. P. Neves, Ed., Atheneu, São Paulo, Brazil, 12th edition, 2011.

[6] F. A. C. De Mendonça, K. F. S. Da Silva, K. K. Dos Santos, K. A. L. Ribeiro Júnior, and A. E. G. Sant'Ana, "Activities of some Brazilian plants against larvae of the mosquito Aedes aegypti," Fitoterapia, vol. 76, no. 7-8, pp. 629-636, 2005.

[7] W. S. Garcez, F. R. Garcez, L. M. G. E. da Silva, and L. Hamerski, "Larvicidal activity against Aedes aegypti of some plants native 
to the West-Central region of Brazil," Bioresource Technology, vol. 100, no. 24, pp. 6647-6650, 2009.

[8] A. R. Roel, "Utilização de plantas com propriedades inseticidas: uma contribuição para o desenvolvimento rural sustentável," Revista Internacional de Desenvolvimento Local, vol. 1, pp. 4350, 2001.

[9] A. Ghosh, N. Chowdhury, and G. Chandra, "Plant extracts as potential mosquito larvicides," Indian Journal of Medical Research, vol. 135, no. 5, pp. 581-598, 2012.

[10] M. L. Wiesbrook, "Natural indeed: Are natural insecticides safer and better than conventional insecticides?" Illinois Pesticide Review, vol. 17, p. 1, 2004.

[11] P. Vasudevan, S. Kashyap, and S. Sharma, "Tagetes: a multipurpose plant," Bioresource Technology, vol. 62, no. 1-2, pp. 29-35, 1997.

[12] P. M. Smith, "Agricultural Plants. By R. H. M. Langer and G. D. Hill. Cambridge: Cambridge University Press (1982), pp. 344," Experimental Agriculture, vol. 18, no. 04, p. 415, 1982.

[13] V. C. Souza and H. Lorenzi, "Botânica Sistemática: Guia ilustrado para identificação das famílias de Angiospermas da flora brasileira em APG II," Instituto Plantarum, vol. 2, 2005.

[14] K. Yasukawa and Y. Kasahara, "Effects of flavonoids from French Marigold (Florets of Tagetes patula L.) on acute inflammation model," International Journal of Inflammation, vol. 2013, Article ID 309493, 5 pages, 2013.

[15] Y. R. Chadha, “Tagetes Linn (Compositae)," The Wealth of India, vol. 10, pp. 109-112, 1976.

[16] R. M. Restello, C. Menegatt, and A. J. Mossi, "Efeito do óleo essencial de Tagetes patula L. (Asteraceae) sobre Sitophilus zeamais Motschulsky (Coleoptera, Curculionidae)," Revista Brasileira de Entomologia, vol. 53, no. 2, pp. 304-307, 2009.

[17] M. A. Ayub, A. I. Hussain, M. A. Hanif et al., "Variation in phenolic profile, b-carotene and flavonoid contents, biological activities of two Tagetes species from Pakistani flora," Chemistry Biodiversity, vol. 14, 2017.

[18] S. Faizi, A. Dar, H. Siddiqi et al., "Bioassay-guided isolation of antioxidant agents with analgesic properties from flowers of Tagetes patula," Pharmaceutical Biology, vol. 49, no. 5, pp. 516525, 2011.

[19] T. Rajasekaran, G. A. Ravishankar, and B. Obul Reddy, "In vitro growth of Tagetes patula L. hairy roots, production of thiophenes and its mosquito larvicidal activity," Indian Journal of Biochemistry and Biophysics, vol. 3, no. 1, pp. 92-96, 2004.

[20] F. A. S. Politi, G. M. Figueira, A. M. Araújo et al., "Acaricidal activity of ethanolic extract from aerial parts of Tagetes patula L. (Asteraceae) against larvae and engorged adult females of Rhipicephalus sanguineus (Latreille, 1806)," Parasites \& Vectors, vol. 5, no. 1, article no. 295, 2012.

[21] F. A. S. Politi, G. M. Queiroz-Fernandes, E. R. Rodrigues, J. A. Freitas, and R. C. L. R. Pietro, "Antifungal, antiradical and cytotoxic activities of extractives obtained from Tagetes patula L. (Asteraceae), a potential acaricide plant species," Microbial Pathogenesis, vol. 95, pp. 15-20, 2016.

[22] I. Chkhikvishvili, T. Sanikidze, N. Gogia et al., "Constituents of French Marigold (Tagetes patula L.) Flowers Protect Jurkat TCells against Oxidative Stress," Oxidative Medicine and Cellular Longevity, vol. 2016, Article ID 4216285, 2016.

[23] R. Saleem, M. Ahmad, A. Naz, H. Siddiqui, S. I. Ahmad, and S. Faizi, "Hypotensive and toxicological study of citric acid and other constituents from Tagetes patula roots," Archives of Pharmacal Research, vol. 27, no. 10, pp. 1037-1042, 2004.
[24] Y. K. Vasilenko, A. N. Bogdanov, L. M. Frolova, and A. V. Frolov, "Hepatoprotective properties of preparations made from spreading marigold," Khimiko-Farmatsevticheskii Zhurnal, vol. 24, no. 1, pp. 53-56, 1990.

[25] C. Wells, W. Bertsch, and M. Perich, "Insecticidal volatiles from the marigold plant (genus tagetes). Effect of species and sample manipulation," Chromatographia, vol. 35, no. 3-4, pp. 209-215, 1993.

[26] A. P. Buena, M. Á. Díez-Rojo, J. A. López-Pérez, L. Robertson, M. Escuer, and A. Bello, "Screening of Tagetes patula L. on different populations of Meloidogyne," Crop Protection, vol. 27, no. 1, pp. 96-100, 2008.

[27] S. Faizi, S. Fayyaz, S. Bano et al., "Isolation of nematicidal compounds from Tagetes patula L. yellow flowers: Structureactivity relationship studies against cyst nematode Heterodera zeae infective stage larvae," Journal of Agricultural and Food Chemistry, vol. 59, no. 17, pp. 9080-9093, 2011.

[28] K. Anani, J. B. Hudson, C. De Souza et al., "Investigation of medicinal plants of Togo for antiviral and antimicrobial activities," Pharmaceutical Biology, vol. 38, no. 1, pp. 40-45, 2000.

[29] S. Faizi, H. Siddiqi, S. Bano et al., "Antibacterial and antifungal activities of different parts of Tagetes patula: Preparation of patuletin derivatives," Pharmaceutical Biology, vol. 46, no. 5, pp. 309-320, 2008.

[30] V. C. Filho and R. A. Yunes, "Estratégias para a obtenção de compostos farmacologicamente ativos a partir de plantas medicinais: conceitos sobre modificação estrutural para otimização da atividade," Química Nova, vol. 21, no. 1, pp. 99105, 1998.

[31] A. L. G. Degani, Q. B. Cass, and P. C. Vieira, "Cromatografia um breve ensaio. Cromatografia," Química Nova na Escola, vol. 7, pp. 21-25, 1998.

[32] L. A. Lacey, "Bacteria: Laboratory biossay of bacteria against aquatic insects with emphasis on larvae of mosquitoes and black flies," in Manual of Techiniques in insect pathology, London, L. A. Lacey, Ed., p. 409, 1997.

[33] World Health Organization, "Determination of the Toxicity of Bacillus thuringiensis subsp. israelensis and B. sphaericus products," in Guideline specifications for bacterial larvicides for public health use, Who/Cds/Cpc/ Whopes, DRAFT, pp. 29-33, 1999.

[34] World Health Organization, "Guidelines for Laboratory an Field Testing of Mosquito Larvicides," 2005.

[35] G. Schmeda-Hirschmann, A. Tapia, C. Theoduloz, J. Rodríguez, S. López, and G. E. Feresin, "Free radical scavengers and antioxidants from Tagetes mendocina," Zeitschrift für Naturforschung C, vol. 59, no. 5-6, 2004.

[36] T. J. Mabry, K. R. Markham, and M. B. Thomas, The Systematic Identification of Flavonoids, Springer Berlin Heidelberg, Berlin, Heidelberg, 1970.

[37] I. Parejo, O. Jáuregui, F. Viladomat, J. Bastida, and C. Codina, "Characterization of acylated flavonoid-O-glycosides and methoxylated flavonoids from Tagetes maxima by liquid chromatography coupled to electrospray ionization tandem mass spectrometry," Rapid Communications in Mass Spectrometry, vol. 18, no. 23, pp. 2801-2810, 2004.

[38] A. M. P. Silva, S. R. Paiva, M. R. Figueiredo, and M. A. C. Kaplan, "Atividade biológica de naftoquinonas de espécies de Bignoniaceae," Revista Fitos, vol. 7, no. 4, pp. 207-215, 2012.

[39] M. Lechtenberg, B. Quandt, and A. Nahrstedt, "Quantitative determination of curcuminoids in Curcuma rhizomes and 
rapid differentiation of Curcuma domestica Val. and Curcuma xanthorrhiza Roxb. by capillary electrophoresis," Phytochemical Analysis, vol. 15, no. 3, pp. 152-158, 2004.

[40] E.-H. Liu, L.-W. Qi, J. Cao, P. Li, C.-Y. Li, and Y.-B. Peng, "Advances of modern chromatographic and electrophoretic methods in separation and analysis of flavonoids," Molecules, vol. 13, no. 10, pp. 2521-2544, 2008.

[41] C. S. Bizzotto, A. D. Meinhart, C. A. Ballus, G. Ghiselli, and H. T. Godoy, "Comparison of capillary electrophoresis and high performance liquid chromatography methods for caffeine determination in decaffeinated coffee," Food Science and Technology, vol. 33, no. 1, pp. 186-191, 2013.

[42] N. Komalamisra, Y. Trongtokit, Y. Rongsriyam, and C. Apiwathnasorn, "Screening for larvicidal activity in some Thai plants against four mosquito vector species," Southeast Asian Journal of Tropical Medicine and Public Health, vol. 36, no. 6, pp. 14121422,2005 


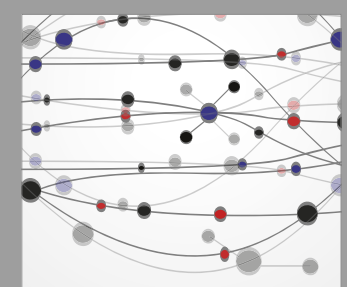

The Scientific World Journal
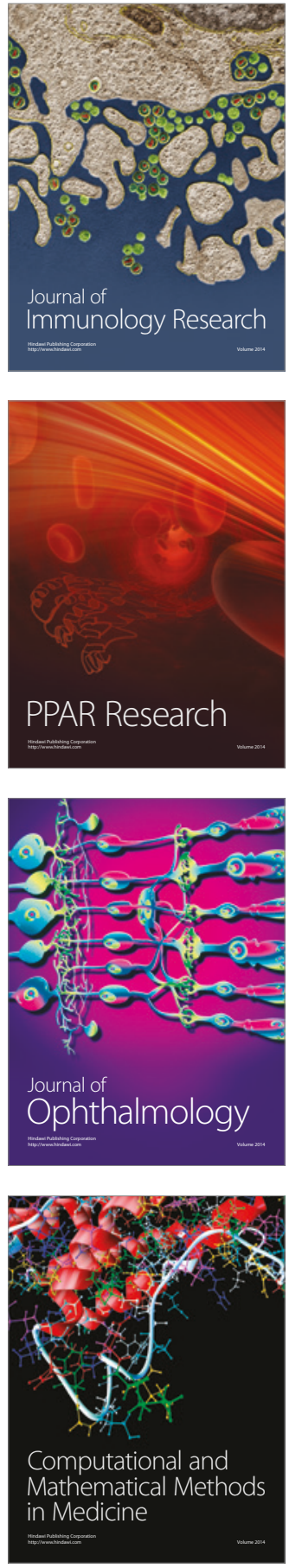

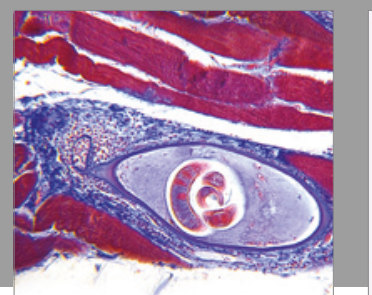

Gastroenterology Research and Practice
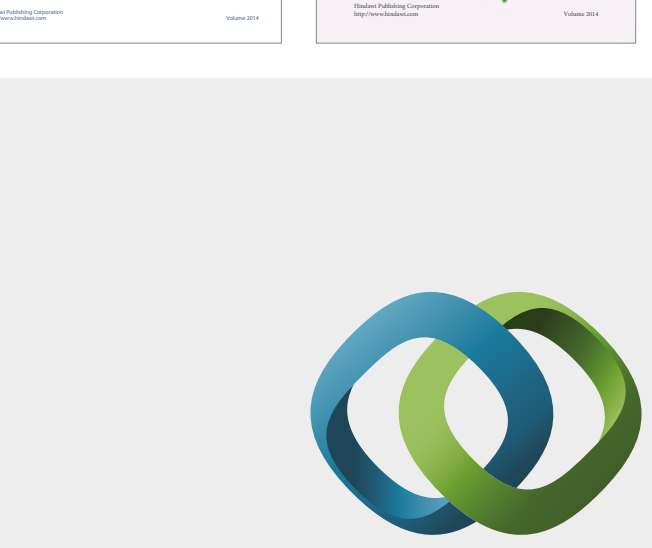

\section{Hindawi}

Submit your manuscripts at

https://www.hindawi.com
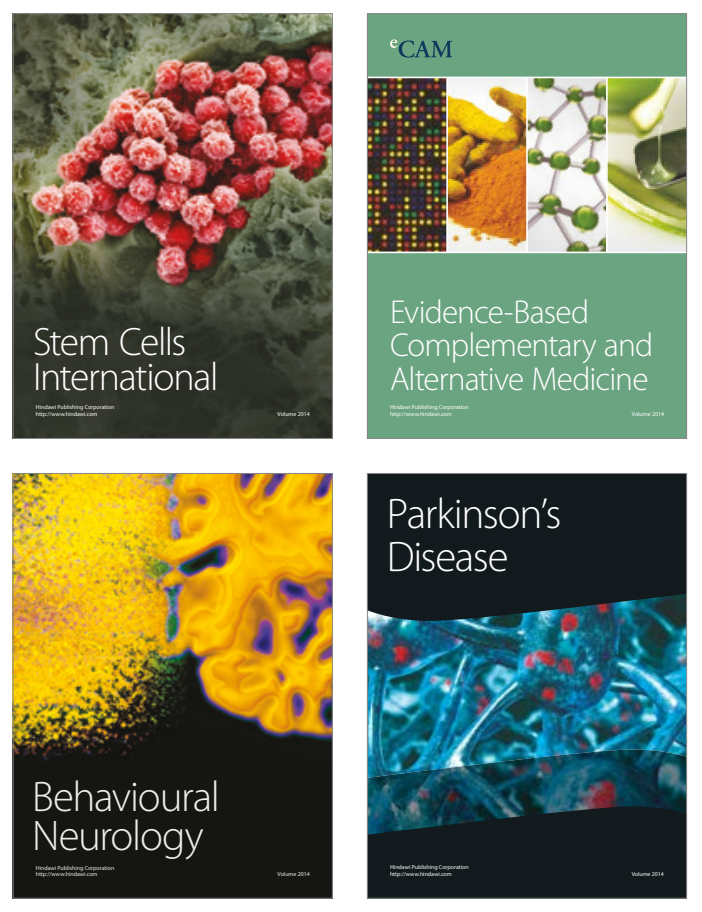
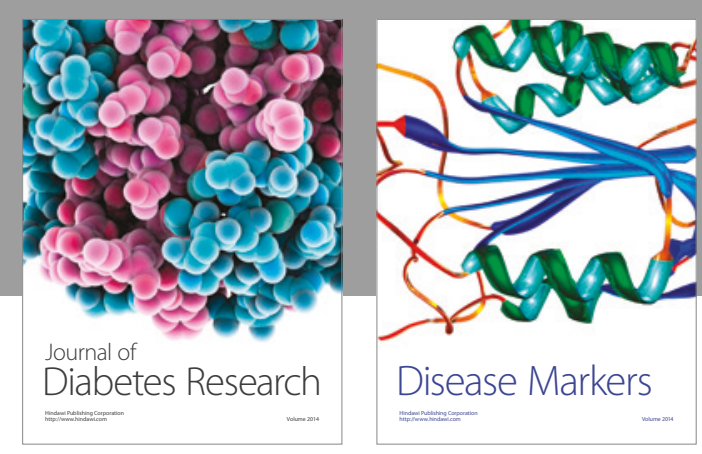

Disease Markers
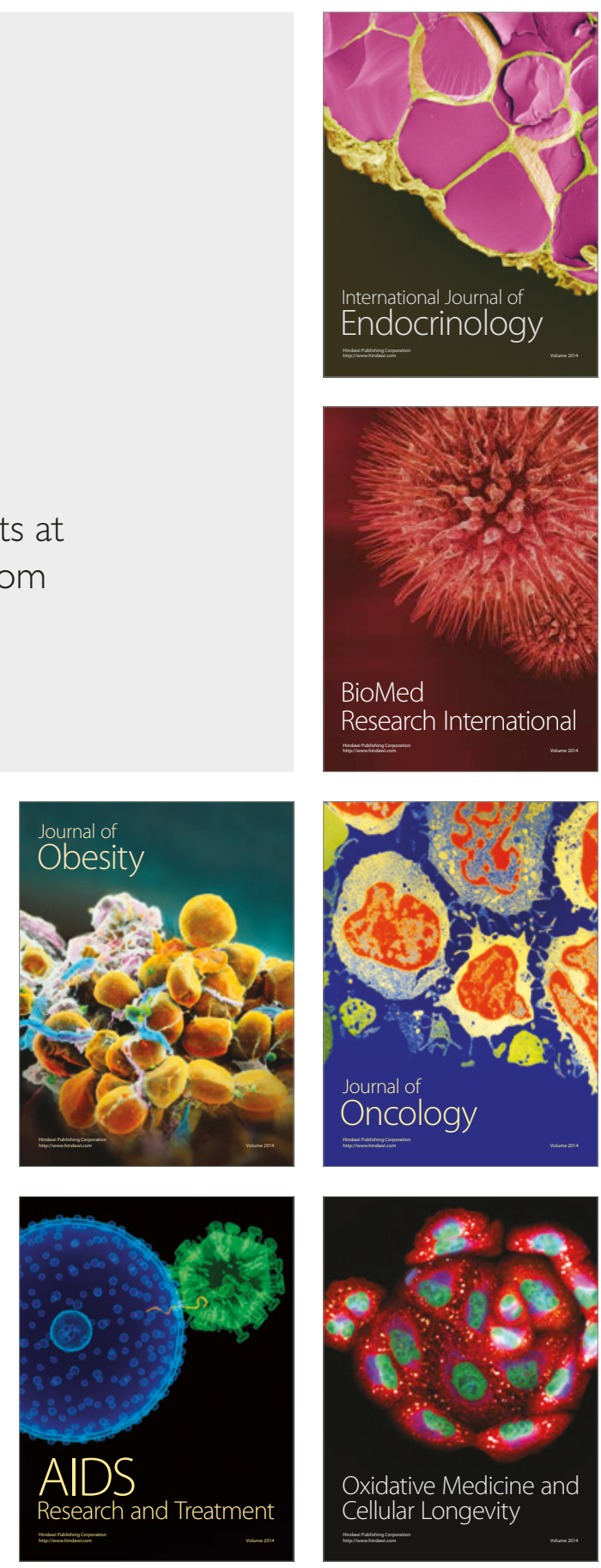